\title{
Ten Years of eLearning within the Engineering Education in the Czech Republic
}

\author{
http://dx.doi.org/10.3991/ijep.v2i3.2095 \\ I. Simonova and M. Bilek \\ University of Hradec Kralove, Hradec Kralove, Czech Republic
}

\begin{abstract}
This paper deals with the process of eLearning implementation in engineering education. It is structured into four parts which (1) analyze this process in the Czech Republic, (2) evaluate the contribution of eLearning seminars, conferences and competitions held at the Faculty of Informatics and Management, University of Hradec Kralove, Czech Republic, (3) provide reflection of the situation in current research activities in this field and (4) present data collected at the University of Hradec Kralove.
\end{abstract}

Index Terms - case study, didactics; eLearning, engineering education, ICT, implementation of eLearning.

\section{INTRODUCTION}

The Czech Republic has joined the European Union strategy in the field of education and information and communication technologies have become common for (nearly) each individual and the whole society - these are two main theses which have influenced the current system of education in the Czech Republic and evoked qualitative and quantitative changes in this field, e.g. the transformation of the existing structure of the educational system, defining new competences and their reflection in the learning content; calling for new teaching methods, organizational forms, ways of evaluation and new relations between elements participating in the educational process; emphasizing Humanities, foreign languages, Informatics, Environmentalistics, learner's responsibility for his/her own education, creativeness and motivation; introducing economic aspects of education; and last but not least the necessity of lifelong education appeared. Furthermore, the world-wide process of globalization brings not only great changes and chances but also requires more competences from people participating in it. Only an educated individual, creative in thinking and doing, flexible enough to solve still unknown problems is able to succeed in such a society. The increased requirements can be met by improving the quality of the educational process. The new structure, relations and social activities have appeared, based on the human competence to predict the social development, accept running changes, developments and trends, and adjust the educational concept (content and methods, forms etc.) to the new situation. The role of technical education and pre-graduate preparation of technical subject teachers is steadily increasing. The main objective of the current society in the field of engineering education is to remove the traditional encyclopaedic content and point of view and introduce another approach which emphasizes student's activity and responsibility for his/her development and education, which is particularly topical problem these days and the main reason why the general analysis, partial results of which are presented below, was required.

\section{CASE Study Description}

\section{A. Objectives and Structure}

The process of ICT implementation, despite it started later in the Czech Republic than in other developed European countries, was running fast, being endorsed and obstructed by its supporters and opponents, as it is common with every new phenomenon. The main task of ICT implementation is to optimize the educational process. Such an approach does not only mean adding new means, methods and forms to the existing ones, it requires revising the whole system, and active ICT implementation in the educational process. McLuhan saying "Medium Is the Message" agreed with both the strengths of media and fears whether the knowledge is really more important that the medium which carries it [1]. Zlamalova emphasizes institutions approach differently to the process of ICT implementation [2]. Some institutions (mostly those which provide technical study programmes) pay more attention to the technical and technological equipment and the didactic principles are often not applied in the process. The technical point of innovations in the educational process is often overestimated but technologies are not the only means to guarantee the effectiveness of the process. On the other side faculties preparing technical subject teachers enforce the didactic approach, they do not implement modern technologies into curricula so quickly, but once they do this, pre-graduate teachers should be well-prepared and highly qualified. Thus modern technologies can be applied in accord with didactic rules; and the main task of engineering pedagogy here is to focus on methodological aspects of this process.

The case study deals with the process of ICT-supported instruction at Czech universities preparing engineers and technical subject teachers. It focuses on four main fields:

a) first, the course of the ICT implementation,

b) second, the analysis of history of seminars, conferences and competitions on eLearning from the point of participating institutions, topics solved, e-products and contributions etc.,

c) third, the evaluation of research studies on eLearning in engineering education and pre-graduate preparation of technical teacher training,

d) fourth, presenting the research data collected at the University of Hradec Kralove. 


\section{B. Technological and Didactic Approach to eLearning}

The history of eLearning being short, the terminology has not been completely set and defined. The definition of the term eLearning arose from different approaches to this phenomenon which originates from its structure. The term of eLearning consists of the original word learning and prefix $e$ - which indicates the relation to computers and the Internet. The whole expression describes a current approach to education using modern technologies, computer networks and appropriate applications, i.e. the educational process supported by information and communication technologies. Both the eLearning and its definitions are under the development. The non-unified terminology, definition (and the graphic form) are caused by different points of views on this field, and by the environment, where eLearning is used, from the technological or/and didactic view.

At the beginning of the implementation process numerous Czech authors emphasized the technological view of eLearning, e.g. Kveton understands eLearning as a tool for creating, updating, distributing and evaluating the process of education via net technologies and the computer, saying "eLearning includes a wide spectrum of applications and processes as Web Based Training, Computer Based Training, creating virtual classes or running digital co-operation [3]. It covers providing and distribution of learning contents via the Internet or Intranet (WAN/LAN), the satellite transmission, interactive TV broadcasting and educational CD-ROMs". This definition mainly focuses on technological approach with respect to ways of transmitting the learning content. Another approach is presented by those authors who highlight eLearning in the environment of computer networks and the Internet. Other authors emphasize the multimediality of eLearning, they understand it as "a multimedia ICT support of the educational process towards improving the quality of education", e.g. Nocar [4]. On the other hand, some authors do not relate eLearning to computer networks; they consider it to be such a process of instruction which is supported by CD/DVD ROMs. Kopecky defines e-learning as "a way of using electronic material didactic means towards efficient reaching the learning objective mainly/not only via computer networks. In the Czech environment it relates mainly to direct learning in the learning management system" [5]. Another approach is introduced by the Hewlett-Packard company, which understands e-learning to be "a way of education using presentations and texts with links, animations, video-recordings, shared work boards, voice comments, student's notes, communication with the lecturer (tutor) and other learners, tests, electronic models of processes etc.“ [6].

All these approaches closely relate to the eLearning development. At the beginning, the process of implementation was managed by IT and technical specialists. This phase can be understood as the above mentioned $e$ - prefix. The other part of the word, learning, appeared in definitions and was emphasized later on, during the further development of the process. Wagner defines eLearning as "the educational process which uses information and communication technologies for designing courses, distributing the learning content, for teacher-learner and learner-learner communication and managing the whole process“" [7]. Another, very simple, definition is presented in the eLearning Action Plan by the European Commission - eLearning means "using modern multimedia tech- nologies and the Internet towards improving the quality of education thanks to easy approach to sources and services“" $[8]$.

As it can be seen from the above mentioned, eLearning can be considered from two different points of view. First, it is the educational process supported by information and communication technologies; second, it is a set of technological tools supporting education. Zlamalova emphasizes that under no circumstances eLearning means the technical " $e-$ " only, but the traditional didactic "-learning" must not be omitted [9]. A completely different approach is introduced by Logan who defines "The $\boldsymbol{e}$ doesn't stand for electronic. Better to think of the $\boldsymbol{e}$ as evolving, or everywhere, or enhanced or extended ... and don't forget $\boldsymbol{e}$ ffective" [10].

The graphic form of the term of eLearning as it can be seen in the analyzed eLearning conference proceedings below as well as in other documents was also the subject of development; e.g. before 2002 Zlamalova uses "elearning", later on "eLearning", which is more complicated from the point of using the Word processor. Poulova used to apply the hyphen form, i.e. "e-learning", since 2004 the form of "eLearning" has been used. Other Czech authors, e.g. Mares, use the traditional form, i.e. "elearning". In this work the form of "eLearning" is used, in cited parts the original form is kept.

\section{The process of eLearning implementation at Czech Universities}

At the beginning of 2009 the research was held at the University of Hradec Kralove analyzing the annual reports of Czech public universities. The research sample covered the period of 1999 - 2008. Twenty-five educational institutions were included in the whole research. Totally, 180 annual reports were analyzed within the research. Collected data underwent the critical analysis, evaluation and discussions. Results are structured according to

a) the chronological point of view,

b) the selection of the appropriate LMS,

c) establishing the special department or institute of eLearning,

d) education of academic staff in eLearning,

e) gaining and providing financial sources,

f) evaluation of eLearning products created by academic staff at the university.

The course of the process of eLearning implementation at Czech Universities is displayed in table 1 (Chronology of the process).

From the chronological point of view the electronic support of instruction was first mentioned in the annual report of the University of Ostrava in 1999, running in the form of $60 \mathrm{CD}-\mathrm{ROMs}$ accessible from the university network. The LMS LearningSpace, which started to work at the university, provides interactive educational courses available via the Internet.

In 2000 information on eLearning appeared in annual reports of several other universities - the University of Hradec Králové (using the distance courses in the virtual learning environment on the Internet), University of Economics, Prague (starting the project on eLearning, planning the course for academic staff on using the LMS 
TABLE I.

CHRONOLOGY OF THE PROCESS

\begin{tabular}{|l|l|l|l|l|l|l|l|l|l|}
\hline & $\mathbf{1}$ & $\mathbf{2}$ & $\mathbf{2}$ & $\mathbf{2}$ & $\mathbf{2}$ & $\mathbf{2}$ & $\mathbf{2}$ & $\mathbf{2}$ & $\mathbf{2}$ \\
$\mathbf{9}$ & $\mathbf{0}$ & $\mathbf{0}$ & $\mathbf{0}$ & $\mathbf{0}$ & $\mathbf{0}$ & $\mathbf{0}$ & $\mathbf{0}$ & $\mathbf{0}$ \\
$\mathbf{9}$ & $\mathbf{0}$ & $\mathbf{0}$ & $\mathbf{0}$ & $\mathbf{0}$ & $\mathbf{0}$ & $\mathbf{0}$ & $\mathbf{0}$ & $\mathbf{0}$ \\
& $\mathbf{9}$ & $\mathbf{0}$ & $\mathbf{1}$ & $\mathbf{2}$ & $\mathbf{3}$ & $\mathbf{4}$ & $\mathbf{5}$ & $\mathbf{6}$ & $\mathbf{7}$ \\
\hline
\end{tabular}

Czech Technical U Prague

${ }^{*}$ Charles U, Prague

Czech U of Life

Sciences, Prague

Inst. of Chem. Technology, Prague

U of Economics
Prague

Technical U, Brno

*Masaryk U, Brno

Mendel U, Brno

*Palacky U, Olomouc

${ }^{*} \mathrm{U}$ of Ostrava

Technical U, Ostrava

Technical U, Liberec

U of Hradec Kralove

U of Pardubice

*UJEP, Usti

Tomas Bata U

*U of West Bohemia

U of South Bohemia

*Silesian U

WebCT and LearningSpace) and University of Ostrava (using the LMS LearningSpace where supportive courses for the interactive instruction were saved).

In 2001 eLearning activities were described in ten annual reports listed below:

- Czech Technical University, Prague (integrating ICT into education within the long-term plan, piloting eLearning projects and running five eLearning courses);

- University of Ostrava (establishing the Department of eLearning within the IT Centre, organizing academic staff training in methodology of the distance education, and selecting the appropriate LMS);

- Silesian University, Opava (starting to build the virtual university while working in the LMS Tutor 2000);

- University of Hradec Kralove (focusing on preparing e-subjects for university study programmes and eLearning courses for the public; organizing OLIVA (On-LIne VýukA, i.e. on-line instruction) seminars for academic staff, and solving first eLearning projects;

- Jan Evangelista Purkyne University (UJEP), Usti nad Labem (building the infrastructure and buying a video-server);

- VSB-Technical University of Ostrava (creating learning texts for combined and present form of study at university web pages);

- University of Economics, Prague (focusing on receiving accreditation of the eLearning distance study programme and organizing seminars for academic staff);

- Institute of Chemical Technology, Prague (starting to build the virtual library of electronic learning texts at university web pages).

- The Mendel University of Agriculture and Forestry, Brno, stated no eLearning activities in 2001. The other universities did not mention eLearning in their annual reports.

In 2002 other universities implemented eLearning in the educational process Czech University of Life Sciences, Prague, University of South Bohemia, Ceske Budejovice, Technical University of Liberec and Tomas Bata University, Zlin. The Mendel University of Agriculture and Forestry, Brno, started to solve the eLearning infrastructure.

In 2003 the eLearning related activities were mentioned in most universities, with the exception of those which did not present their annual reports on university web pages (i.e. University of Pardubice and University of West Bohemia, Plzen, which published the 2007 annual reports only. eLearning activities were mentioned in both, but it is widely known the process started several years before there. Thus we can conclude that in 2007 all institutions preparing engineers and technical subject teachers started the process of ICT implementation.

The efficiency of eLearning implementation within the university closely relates to the Learning Management System which provides the support. The type of LMS was defined in $80 \%$ of annual reports. Most universities decided to work in one LMS and continue its development; 16 institutions had run two systems before selected the most appropriate one. Other important facts dealing the LMS are as follows:

- the LMS Moodle was the most frequently used one; it was used by nine universities.

- Other LMSs followed: Tutor 2000 or iTutor (3 universities), LearningSpace (3), WebCT (2), eDoceo (2), EDEN (2), MS Class Server (2), Unifor (1), IBM Workplace Collaborative Learning (1) and Oracle eLearning (1). FIM UHK also used the LearningSpace first, after a short period the priority was given to LMS WebCT.

- Six universities developed or were developing their own LMS (Czech University of Life Sciences, Prague, University of South Bohemia, Ceske Budejovice, Masaryk University, Brno, Mendel University of Agriculture and Forestry, Brno Technical University of Liberec, VSB-Technical University of Ostrava).

- Four universities changed the LMS three or more times during the monitored period (University of Ostrava, Jan Evangelista Purkyne University, Usti nad Labem, VSB-Technical University of Ostrava, University of Economics, Prague).

Independent departments were established at numerous universities, usually called Centre of eLearning support, Laboratory of virtual education, Centre of e-support of education, eLearning department, etc. They either were structured under ICT centres, or they worked independently at several universities. Within the research period such departments were established at all institutions. 
PAPER

TEN YEARS OF ELEARNING WITHIN THE ENGINEERING EDUCATION IN THE CZECH REPUBLIC

The annual reports were also analyzed from the point of academic staff education focused on both technological and didactic field of ICT implementation so that they were able to reach media literacy for education, and thus apply appropriate teaching methods to make the process of instruction efficient. In 2000 the academic staff training in the methodology of the distance education ran at University of Economics, Prague. This institution belonged to the first ones which received accreditation for a bachelor study programme in the distance form. In 2001 two universities mentioned the academic staff education (University of Hradec Kralove and University of Ostrava). In 2002 other five institutions joined this progressive group (Czech Technical University, Prague, Czech University of Life Sciences, Prague, Silesian University, Opava, Tomas Bata University, Zlin, and VŠB-Technical University of Ostrava). They all focused on reaching computer literacy in the form of the ECDL Certificate (European Computer Driving Licence), later on this general competence was applied in the field of education, i.e. teacher's didactic preparation for ICT supported instruction, and student's competence to study this way.

Together with the above mentioned criteria the field of financial expenses related to the process of eLearning implementation cannot be omitted. The information provided by universities was mostly very brief. Seventeen institutions mentioned a wide share of project funding, both national and international, which financially support the eLearning activities. Not a university stated any share of its own institution.

Various approaches, which in some cases differ to a large extent, appeared in eLearning evaluation. Most universities introduced their own internal system of quality evaluation. The process seldom ran within the whole university (Technical University of Liberec) but at numerous institutions it was managed by the faculty or department (e.g. Faculty of Informatics and Management and Faculty of Education, University of Hradec Kralove, Faculty of Management and Economics, Tomas Bata University, Zlin). The process usually ran together with the motivation support system towards designing eLearning courses. The motivation systems are often based on the principle of competition when authors of the highly appreciated courses are (financially) awarded (Faculty of Education, UHK, Technical University of Liberec). Another approach was to evaluate according to the predefined criteria. If they are met, the award is provided (Faculty of Informatics and Management, UHK).

The institutions also differed in presenting the evaluated courses, from open presentations to the professional board and public (Faculty of Management and Economics, Tomas Bata University, Zlin, Faculty of Informatics and Management, UHK), to providing materials about the course and running an independent process of evaluation by single board members (Technical University of Liberec, Faculty of Education, UHK).

Some institutions prefer internal process of evaluation (Faculty of Informatics and Management, UHK), others co-operate with external evaluators (Technical University of Liberec). The combination of both approaches was widely used (Faculty of Management and Economics, Tomas Bata University, Zlin, Faculty of Education, UHK).
Authors conclude that despite various approaches to all monitored activities were applied, the main objective was reached, i.e. eLearning became standard at Czech universities. And further development according to the latest trends and scientific results is expected so that the educational process is optimized and tailored to student's needs.

\section{ELEARNING SEMINARS, CONFERENCES, COMPETITIONS}

More than ten years ago a seminar on eLearning was held at the Faculty of Informatics and Management, University of Hradec Králové. Originally an event of little importance has become the weighty conference and competition during the last decade. Reasons why it happened are described below, as well as the ways how the process was running on.

In 2000 the first year of the seminar On the distance education implementation at universities was held. It was organized by the Faculty of Informatics and Management, University of Hradec Kralove, and EUNIS-CZ, which is an independent special-interest association of legal entities, open to others, engaged in introduction, development, control, or use of information system at Czech universities. Participants from several universities had presentations describing the situation at their own institutions, followed by discussions on experience in running distance courses and further co-operation.

In 2001 a two-day seminar was held on the distance education development within the information society. Those days several new events appeared dealing with similar problems. So, a different structure was introduced including a one-day seminar and one-day competition where eLearning products designed in the Czech and Slovak Republic were introduced. That year 11 distance ecourses for gradual and lifelong education were presented. The main objective of the competition was to start the process of designing and using courses supported by modern technologies, evaluate their quality, provide information to the wide public and encourage further cooperation in the field of the distance education and eLearning. Wide and lively discussions of 60 participants continued after the competition.

The following seminars in 2002 - 2005 were organized within the TECHFILM international festival. Since 2002 all contributions have been published in proceedings.

Since 2006 the seminar (7th year) and the competition (6th year) have not been held as part of the TECHFILM festival any more. A new approach was introduced - eproducts in the competition were structured in two groups: the complete distance courses, and single learning objects.

In 2007 the 8th year brought a substantial change in the form of the event. Relating to the wide importance and high number of participants the form of seminar was changed to conference. The new structure of the competition introduced in 2006 worked well, so it was accepted for following years. In 2007 there was no key topic of the conference, which was caused by the fact that single institutions were in different phases of the process of eLearning implementation. The seminar/conference was the opportunity to provide or receive experience, discuss problems, avoid those which had been solved at other universities before. Such a situation resulted in brief information on the events in this analysis despite the discussions were long and enthusiastic, and total number of participants high. 
In 2008 another change in the conference organization was introduced: conference papers were structured to eight sections which were highly topical that time:

- digital television a medium of education,

- eLearning in adult education,

- interuniversity study,

- infrastructure for eLearning,

- methodology of eLearning,

- multimedia study materials,

- case studies and projects,

- educational and psychological aspects of eLearning.

After a ten-year period the seminars/conferences and competitions most participants of the event agreed it had become a firm and contributive part of the process of eLearning implementation to university education. It had gone through numerous changes, widened the extent and updated the content. Within the ten-year period it became a platform for discussions, exchange experience, research activities, it joined the supporters and opponents, and touched various fields relating to the tertiary education. All these activities are worth deep analyses. Key topics which each seminar/conference was devoted to are presented in table 2 .

Following data show the increase in number of participants of seminars $(2000-2006)$, which was one of the reason they smoothly grew into conferences $(2007$ - now), and competitions (2001 - now). The gender analysis of seminars/conferences and competitions provides interesting results supposing the technologies to be (in large measure) the field of male activities and teaching the field of female ones. The total number of 470 active seminar/conference participants includes $39 \%$ of women, their participation in competitions is higher - $48 \%$ (out of 282 active participants). Authors of papers and e-products attending the conference/seminar are considered to be the active participants. Starting from a few womenparticipants in the first years, their number was the highest and even exceeded the number of men-participants in the seminar in 2006. Then it was steadily decreasing. In competitions the highest number of men-participants was recorded in 2004 (38), followed by 2007 (24). The highest number of women-participants was recorded in 2003 (24) and 2007 (23). Following, more detailed, gender analyses might focus on women-share in designing e-products and running e-courses relating to technical subjects. The results are displayed in figure 1.

The process of quantitative increase having been finished, the qualitative changes followed expressing the shift in the content of contributions and target groups within the monitored period. As for the type of contributions in the first years they were mostly descriptive introducing new e-courses and the process of designing them. The higher the number of e-courses was, the amount of contribution of this type was increasing. Consequently other types of contributions arose providing experience exchange and discussions on running the courses, not only from the technical and technological point of view but also methodological and didactic topics were gradually emerging. Then, various approaches to evaluation from student's side and the results were presented (contributions providing teacher's and tutor's feedback seldom appeared), quantitative researches of study results, often in the form of comparative studies of traditional face-to-face and ICT supported instruction; analyses of results and other more demanding and complicated methods were sometimes applied and described. Running the analyses is mostly complicated by the fact that it is difficult to define the type of contribution, as the content is often "mixed", e.g. partly theoretical, supported by author's personal experience, or the content does not fully relate to the title of the contribution, etc. Data presented in table 3 confirm the above described facts.

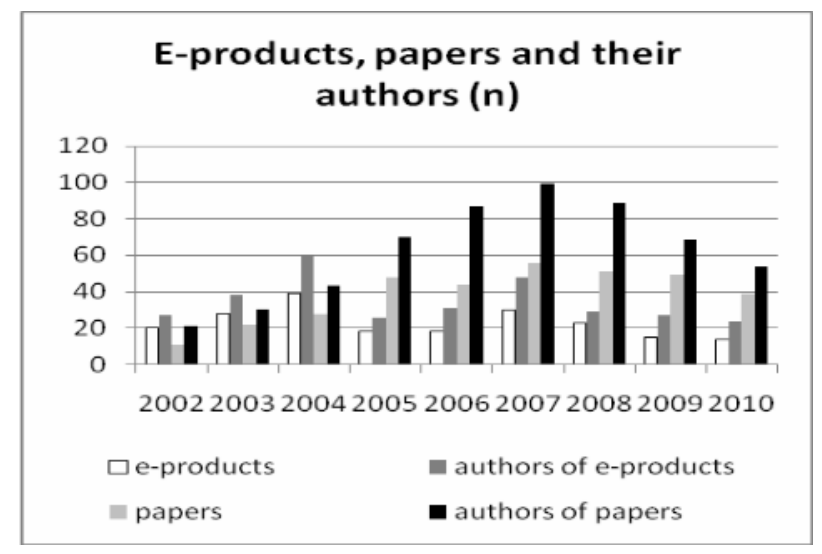

Figure 1. E-products, papers and their authors

TABLE II

KEY CONFERENCE TOPICS

\begin{tabular}{|l|l|}
\hline Year & \multicolumn{1}{|c|}{ Topic } \\
\hline 2002 & $\begin{array}{l}\text { Co-ordination of the distance education development at } \\
\text { universities }\end{array}$ \\
\hline & Evaluation of the last year's e-learning competition \\
\hline 2003 & Quality evaluation in electronic education \\
\hline 2004 & $\begin{array}{l}\text { Digital library DILLEO, developed at the Faculty of } \\
\text { Informatics and Management, UHK }\end{array}$ \\
\hline 2005 & Efficiency of eLearning \\
\hline 2006 & Five years afterwards \\
\hline 2007 & panel discussions on experience in eLearning \\
\hline 2008 & Emotions of students and teachers in e-learning \\
\hline 2009 & Ten years afterwards \\
\hline 2010 & Role of graphic information in eLearning \\
\hline
\end{tabular}

TABLE III.

TYPES OF CONTRIBUTIONS

\begin{tabular}{|c|c|c|c|c|c|}
\hline & D & T + E & E & A + E & R, S \\
\hline 2002 & 5 & 4 & 1 & 0 & 1 \\
\hline 2003 & 4 & 12 & 2 & 4 & 0 \\
\hline 2004 & 4 & 15 & 6 & 3 & 2 \\
\hline 2005 & 19 & 18 & 4 & 4 & 3 \\
\hline 2006 & 20 & 10 & 6 & 4 & 4 \\
\hline 2007 & 32 & 12 & 9 & 1 & 2 \\
\hline 2008 & 26 & 3 & 11 & 5 & 2 \\
\hline 2009 & 18 & 2 & 3 & 3 & 3 \\
\hline 2010 & 16 & 8 & 8 & 4 & 3 \\
\hline
\end{tabular}

$D$ - description of e-product, course, project

$T+E$ - theory and experience

$E$ - experience only

$A+E$ - analysis, experience

$R, S$ - research, survey 
PAPER

An adequate shift was observed in the range and order of subjects and fields supported by ICT, i.e. where eLearning was applied. It is natural the process started in ICT related subjects and the first authors (designers) of ecourses were IT professionals. This fact resulted in such a situation when some e-courses were a random exhibition (or database) of tools provided by a learning management system, without any didactic application of the tools Economic and managerial subjects supported by ICT followed. In a narrow range the ICT were implemented in foreign language, humanities and natural science instruction, followed by e.g. typing, playing the piano, but also learning the sign language etc. Just the last example proves that eLearning really can be applied in a wide range of subjects including institutions with special needs if it is implemented appropriately.

\section{REFLECTION IN CURRENT ANALYSES}

These results can be compared to another analysis in which the authors (Bílek, M., Poulová, P., Šimonová, I., 2009) aimed at occurrence of case studies within three important eLearning conferences in the Czech Republic: ICTE (held at the Faculty of Natural Sciences, University of Ostrava, 2000 - 2008); SCO (Masaryk University, Brno, 2005 - 2007); and eLearning (Faculty of Informatics and Management, University of Hradec Králové, 2002 - 2008). Eighty-one case studies were included in the research (out of several hundreds) which were defined to be the research studies by their authors. Following criteria were applied within the analysis:

a) methodology of research,

b) explicitness of research hypotheses,

c) research sample,

d) statistical processing of the collected data.

From the point of the research methodology the experience proved that explorative methods were frequently applied in pedagogical research as well as in researching eLearning, its applications and products. The method of questionnaire was used in 52 and interview in three case studies out of 81 . The pedagogical experiment was applied in 14 research projects, nine authors used study result analysis of e-course students, two authors employed the method of observation. One study aimed at developing the research methodology towards measuring the eLearning efficiency. The structure of applied research methods is displayed in figure 2 .

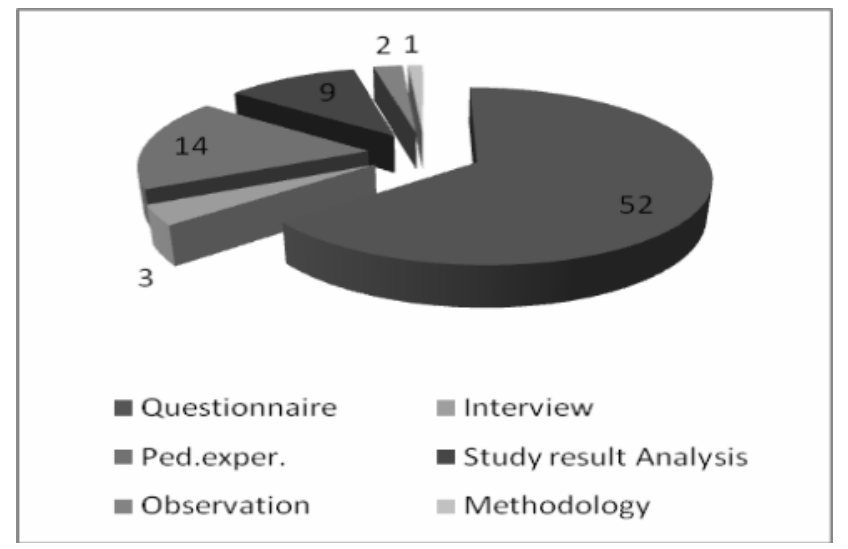

Figure 2. Research Methods
Research hypotheses were explicitly defined in nine studies only, which was consequently reflected in vaguely-defined scientific problems and research objectives of the other studies.

The research sample was described in 58 studies. As presented in figure 2, the number of respondents differed from fewer than 100 respondents in 27 studies, $101-499$ respondents in 25 studies, and six research projects included more than 500 respondents. The research sample was not described in 23 studies.

The way of statistical processing was described in 63 studies - in 54 studies only the basic descriptive statistics was provided, 18 studies did not contain any statistical analyses despite they had been declared, and the qualitative statistics was included in one study.

As it can be seen from the collected data, numerous authors deal with research in eLearning. They mostly use traditional methods of pedagogical research, the questionnaire method is the most frequently applied one. Considering the fact eLearning is quite a new phenomenon, innovative approach should be used and new, non-traditional methods employed, e.g. virtual observation and tracking instead of direct and indirect observation, a wider deal of qualitative methods, case studies and socio-metric methods etc.

There are numerous other views and criteria which could be starting points for following researches and analyses. They might discover relations and approaches how to make the process of eLearning easier, more efficient and student-friendly. To increase its efficiency is one of the closer objectives which could be reached e.g. by adjusting the learning environment so that various individual learning styles could be accommodated.

\section{ELREARNING AT THE UNIVERSITY OF HRADEC KRALOVE}

The LMS WebCT has been used since 2001 at the Faculty of Informatics and Management, University of Hradec Kralove. While providing 80 e-courses in 2004/5 academic year, more than 170 ones supporting a complete range of subjects were created up to 2009/10 [11]. The ICT-supported process is continuously monitored and feedback is collected by a questionnaire filled by both students and teachers regularly every year, and from interviews running continuously during the years. The comparison of three-year results of 2003/4, 2006/7 and $2009 / 10$ academic years is provided below.

\section{A. Questionnaire description}

The questionnaire consists of 45 items structured in three fields. Part One provides information on the sample group. Questions monitor students' previous study experience, availability of ICT equipment, accessibility of the educational institution etc. Part Two deals with the quality and students' satisfaction with single tools provided by LMS. In Part three students' opinions on financial requirements are collected. Thirty-one questions of multiple-choice type are included in the questionnaire, fourteen questions require open answers. The questionnaire was used in an electronic form in courses in LMS WebCT, where the results were finally displayed. 


\section{B. Sample group description}

Totally 280 respondents were included in the survey studying Applied Informatics or Information Management part-time study programmes. Their minimum experience in e-learning was completing 10 e-courses in LMS WebCT during their first year of study (in Management, IT English, Database Systems, Mathematics, Applied Information Technologies, i. e. two e-courses in each subject, which either supported the process of instruction, or ran in the distance way). While in 2004 only those ecourse participants who considered it necessary and were willing to provide their opinion participated in the survey (i.e. 57 students, which is $85 \%$ of all students enrolled in the e-course), in 2007 a 2010 the participation was obligatory (i.e. $100 \%$ of students filled in the questionnaire, which are 140 students in 2007 and 83 students in 2010. The return rate is considered satisfactory.

\section{Research Results}

The collected data were processed and summarized in tables below. Results cover three academic years (2003/4, $2006 / 7,2009 / 10)$, and are provided in per cent (\%).

In table 4 results of Part One of the questionnaire are presented, providing basic information on respondents, i.e. number of participants (male, female), year and type of secondary school they graduated from, personal experience in previous university study, accessibility to the educational institution and availability of hardware and software equipment.

TABLE IV.

INFORMATION ON RESPONDENTS

\begin{tabular}{|l|l|c|c|c|}
\hline & \multicolumn{1}{|c|}{ Responses (in \%) } & $\mathbf{2}$ & $\mathbf{2}$ & $\mathbf{2}$ \\
& $\mathbf{0}$ & $\mathbf{0}$ & $\mathbf{0}$ \\
$\mathbf{0}$ & $\mathbf{0}$ & $\mathbf{0}$ & $\mathbf{0}$ \\
$\mathbf{3}$ & $\mathbf{6}$ & $\mathbf{9}$ \\
$\mathbf{1 4}$ & $\mathbf{7}$ & $\mathbf{1 1 0}$ \\
\hline 1 & Male-students & 84 & 86 & 74 \\
\hline 2 & Female-students & 16 & 14 & 26 \\
\hline 3 & School-leaving exam before 2000 & 7 & 36 & 55 \\
\hline 4 & School-leaving exam in 1999-6 & 46 & 28 & 11 \\
\hline 5 & School-leaving exam in 1995-before & 47 & 36 & 34 \\
\hline 6 & School-leaving exam at grammar school & 51 & 33 & 18 \\
\hline 7 & $\begin{array}{l}\text { School-leaving exam at secondary professional } \\
\text { school * }\end{array}$ & 37 & 64 & 67 \\
\hline 8 & $\begin{array}{l}\text { School-leaving exam at secondary vocational } \\
\text { school }\end{array}$ & 10 & 3 & 4 \\
\hline 9 & $\begin{array}{l}\text { School-leaving exam at another type of school (of } \\
\text { art, abroad etc.) }\end{array}$ & 2 & 0 & 11 \\
\hline 10 & $\begin{array}{l}\text { Before starting study at FIM I studied at another } \\
\text { university, and graduated successfully }\end{array}$ & 7 & 2 & 8 \\
\hline 11 & $\begin{array}{l}\text { I did not study at another university before starting } \\
\text { study at FIM }\end{array}$ & 93 & 98 & 92 \\
\hline 12 & $\begin{array}{l}\text { Before starting study at FIM I studied at another } \\
\text { university, but did not graduate successfully: }\end{array}$ & 51 & 50 & 60 \\
\hline 13 & $\begin{array}{l}\text { Before starting study at FIM I studied at a techni- } \\
\text { cal university/college**, but did not graduate } \\
\text { successfully }\end{array}$ & 96 & 80 & 45 \\
\hline 14 & $\begin{array}{l}\text { Before starting study at FIM I studied at a Faculty } \\
\text { of Law, but did not graduate successfully }\end{array}$ & 0 & 0 & 0 \\
\hline 15 & $\begin{array}{l}\text { Before starting study at FIM I studied at a Faculty } \\
\text { of Education of Arts, but did not graduate success- } \\
\text { fully }\end{array}$ & 0 & 6 & 0 \\
\hline 16 & $\begin{array}{l}\text { Before starting study at FIM I studied at a Faculty } \\
\text { of Economics or Management, but did not gradu- } \\
\text { ate successfully }\end{array}$ & 0 & 3 & 15 \\
\hline 17 & Before starting study at FIM I studied at a Faculty & 0 & 3 & 0 \\
\hline
\end{tabular}

As it can be seen the number of male students is substantially higher in all three academic years, but currently the difference is lower and the number of female-students is slightly moving up (items 1,2 ).

Number of "younger" students (i.e. those who graduated in recent years) is increasing. While in 2003/4 nearly half of the students graduated 5-more and 10-more years before they started studying again (46\% and $47 \%$ ), in $2009 / 10$ it was only $7 \%$ of this age-group, and more than half of students $(55 \%)$ graduated fewer than 5 years before they started studying again (items $3-5$ ).

In 2003/4 half of students (51 \%) graduated from grammar schools, followed by $37 \%$ from secondary professional schools (i.e. schools of engineering, machinery engineering, information technology, business academy, etc.). Three years later the trend changed, and in $2006 / 7$ there were $64 \%$ and in 2009/10 even $67 \%$ of enrolled students who graduated form secondary professional schools (items 6-9).

Following items dealt with respondent's previous university study. Fewer than $10 \%$ of students $(2-8 \%)$ had graduated from another university (item 10). The same number started university study but they did not graduate successfully. They studied at technical faculties, faculty of medicine, education or economics (items $11-18$ ). There also appeared few students $(4-6 \%)$ being simultaneously enrolled at another faculty (of education, medicine or technical ones; items $19-26$, figure 3 ).

\begin{tabular}{|c|c|c|c|c|}
\hline & $\begin{array}{l}\text { of Medicine of Pharmacy, but did not graduate } \\
\text { successfully }\end{array}$ & & & \\
\hline 18 & $\begin{array}{l}\text { Before starting study at FIM I studied at a another } \\
\text { type of faculty, or abroad, but did not graduate } \\
\text { successfully }\end{array}$ & 4 & 8 & 0 \\
\hline 19 & $\begin{array}{l}\text { While studying at FIM, I do not study at any other } \\
\text { university }\end{array}$ & 96 & 94 & 96 \\
\hline 20 & $\begin{array}{l}\text { While studying at FIM, I study at another univer- } \\
\text { sity: }\end{array}$ & 4 & 6 & 4 \\
\hline 21 & $\begin{array}{l}\text { While studying at FIM, I study at another univer- } \\
\text { sity** }\end{array}$ & 50 & 33 & 0 \\
\hline 22 & While studying at FIM, I study at a Faculty of Law & 0 & 0 & 0 \\
\hline 23 & $\begin{array}{l}\text { While studying at FIM, I study at a Faculty of } \\
\text { Education of Arts }\end{array}$ & 50 & 33 & 0 \\
\hline 24 & $\begin{array}{l}\text { While studying at FIM, I study at a Faculty of } \\
\text { Economics and Management }\end{array}$ & 0 & 0 & 4 \\
\hline 25 & $\begin{array}{l}\text { While studying at FIM, I study at Faculty of } \\
\text { Medicine or Pharmacy }\end{array}$ & 0 & 33 & 0 \\
\hline 26 & $\begin{array}{l}\text { While studying at FIM, I study at another type of } \\
\text { university, or abroad }\end{array}$ & 0 & 0 & 0 \\
\hline 27 & $\begin{array}{l}\text { I do not commute to FIM, or I commute from max. } \\
59 \mathrm{~km}\end{array}$ & 26 & 46 & 55 \\
\hline 28 & I commute to FIM from $60-109 \mathrm{~km}$ & 32 & 30 & 26 \\
\hline 29 & I commute to FIM from $110-199 \mathrm{~km}$ & 39 & 23 & 19 \\
\hline 30 & I commute to FIM from 200 and more $\mathrm{km}$ & 3 & 1 & 0 \\
\hline 31 & I have got a computer at home: & 93 & 98 & 100 \\
\hline 32 & $\begin{array}{l}\text { I have got a computer with the Internet access at } \\
\text { home }\end{array}$ & 70 & 97 & 100 \\
\hline 33 & $\begin{array}{l}\text { I have got a computer with the high-speed Internet } \\
\text { access at home }\end{array}$ & 37 & 71 & 92 \\
\hline 34 & $\begin{array}{l}\text { I have got a computer with the Internet access at } \\
\text { work which I share with colleagues }\end{array}$ & 21 & 6 & 8 \\
\hline 35 & $\begin{array}{l}\text { I have got a computer with the Internet access at } \\
\text { work which I do not share with anyone }\end{array}$ & 76 & 88 & 81 \\
\hline 36 & I do not have any computer at work & 3 & 6 & 11 \\
\hline
\end{tabular}




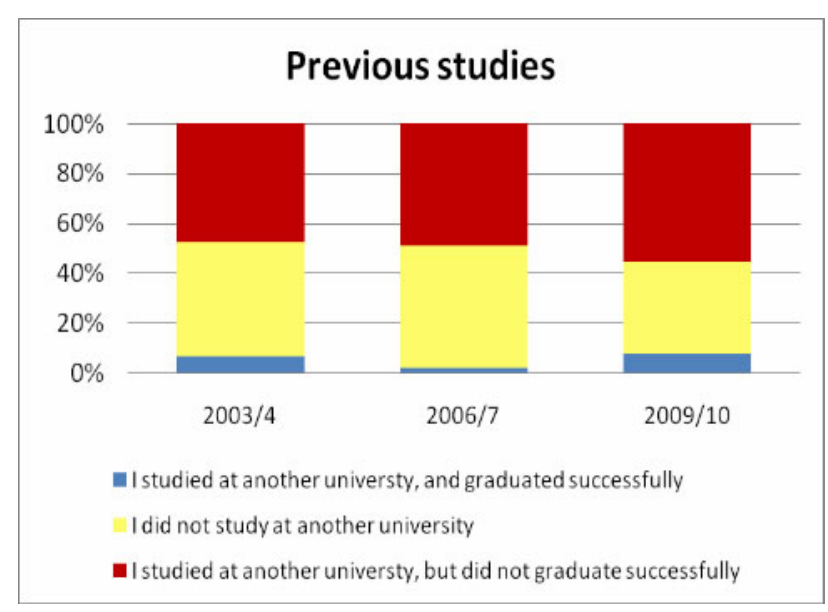

Figure 3. Respondents' previous studies

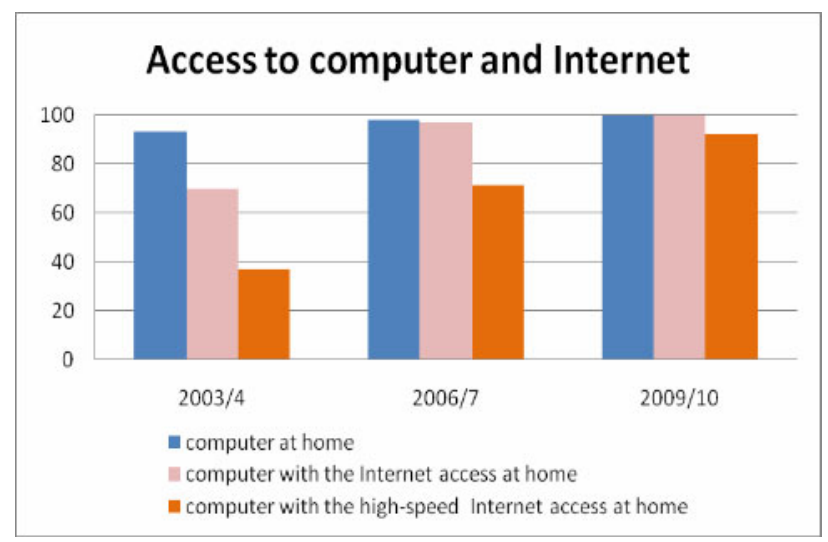

Figure 4. Access to computer and the Internet

The accessibility to the educational institution changed. Number of students who live in the same location where the institution is situated or commute $\max 59 \mathrm{~km}$ is increasing. From $26 \%$ in 2003/4 the number reached $55 \%$ in $2009 / 10$, while the number of long-distance commuters (i.e. commuting $110-199 \mathrm{~km}$ ) was decreasing gradually from 39 to 19 (items $27-30$ ).

The access to computers and the Internet improved. In $2003 / 493 \%$ of students had their own computer at home, $70 \%$ of them with the Internet access, in 2009/10 all respondents state they have a computer with the Internet access at home. These results seem positive but it must be taken into account that respondents were part-time students of Informatics working in this field (items $31-36$, figure 4).

In Part Two of the questionnaire students' satisfaction with the LMS tools was monitored. The collected data are displayed in tables $5-7$.

Table 5 provides figures evaluating students' satisfaction with single tools displayed in the left column. The evaluation scale is structured into seven levels as follows:

Yes $+++(\mathrm{Y}+++)$ expresses complete, full satisfaction with the tool,

Yes $++(\mathrm{Y}++)$ describes a large degree of satisfaction,

Yes $+(\mathrm{Y}+)$ presents a slight degree of satisfaction,

No $-(\mathrm{N}-)$ means a slight degree of dissatisfaction,

No -- (N--) shows a large degree of dissatisfaction,

No --- (N---) indicates complete dissatisfaction.
TABLE V.

EVALUATION OF STUDENTS' SATISFACTION WITH LMS TOOLS (\%)

\begin{tabular}{|l|l|l|l|l|l|l|l|l|l|}
\hline & \multicolumn{3}{|c|}{$\begin{array}{l}\text { Y+++ } \\
\end{array}$} & \multicolumn{3}{|c|}{$\begin{array}{c}\text { Y++ } \\
2003 / 06 / 09\end{array}$} & \multicolumn{3}{c|}{$\begin{array}{c}\text { Y+ } \\
2003 / 06 / 09\end{array}$} \\
\hline Study Materials & 35 & 14 & 26 & 32 & 49 & 37 & 32 & 26 & 26 \\
\hline Dictionary & 24 & 11 & 15 & 18 & 22 & 15 & 23 & 20 & 15 \\
\hline Search & 3 & 11 & 11 & 6 & 11 & 11 & 3 & 13 & 0 \\
\hline Tests Credit & 21 & 33 & 40 & 42 & 39 & 44 & 16 & 23 & 4 \\
\hline $\begin{array}{l}\text { Sample } \\
\text { Test }\end{array}$ & 59 & 74 & 14 & 27 & 11 & 4 & 6 & 11 \\
\hline Syllabus & 45 & 54 & 20 & 30 & 29 & 4 & 16 & 9 & 11 \\
\hline Calendar & 47 & 47 & 50 & 32 & 29 & 29 & 11 & 13 & 4 \\
\hline E-mail & 49 & 49 & 52 & 23 & 24 & 29 & 10 & 6 & 8 \\
\hline $\begin{array}{l}\text { Discussion } \\
\text { Chat A9 }\end{array}$ & 3 & 61 & 63 & 18 & 21 & 29 & 12 & 12 & 0 \\
\hline $\begin{array}{l}\text { Setting Assign- } \\
\text { ments }\end{array}$ & 54 & 39 & 59 & 7 & 3 & 11 & 5 & 5 & 8 \\
\hline $\begin{array}{l}\text { Submitting } \\
\text { assignments }\end{array}$ & 68 & 59 & 33 & 19 & 34 & 52 & 11 & 6 & 3 \\
\hline
\end{tabular}

TABLE VI.

EVALUATION OF STUDENTS' DISSATISFACTION WITH LMS TOOLS (\%)

\begin{tabular}{|c|c|c|c|c|c|c|c|c|c|}
\hline \multirow[b]{2}{*}{ Study Materials } & \multicolumn{3}{|c|}{$\begin{array}{c}\text { N- } \\
2003 / 06 / 09\end{array}$} & \multicolumn{3}{|c|}{$\begin{array}{c}\text { N-- } \\
2003 / 06 / 09\end{array}$} & \multicolumn{3}{|c|}{$\begin{array}{c}\text { N--- } \\
2003 / 06 / 09\end{array}$} \\
\hline & 1 & 1 & 1 & 0 & 0 & 0 & 0 & 0 & 0 \\
\hline Dictionary & 3 & 16 & 11 & 1 & 9 & 0 & 0 & 9 & 0 \\
\hline Search & 2 & 5 & 0 & 0 & 3 & 0 & 0 & 0 & 0 \\
\hline Tests & 5 & 0 & 4 & 0 & 1 & 0 & 0 & 0 & 0 \\
\hline $\begin{array}{|ll|}\text { Sample } & \text { Credit } \\
\text { Test } & \\
\end{array}$ & 0 & 0 & 0 & 0 & 0 & 0 & 0 & 1 & 0 \\
\hline Syllabus & 0 & 1 & 0 & 0 & 0 & 0 & 0 & 0 & 0 \\
\hline Calendar & 5 & 4 & 0 & 0 & 0 & 0 & 0 & 1 & 0 \\
\hline E-mail & 0 & 7 & 0 & 0 & 0 & 0 & 0 & 0 & 0 \\
\hline Discussion & 0 & 0 & 0 & 2 & 0 & 0 & 0 & 0 & 0 \\
\hline Chat & 3 & 6 & 0 & 2 & 0 & 0 & 0 & 3 & 0 \\
\hline $\begin{array}{ll}\begin{array}{l}\text { Setting } \\
\text { ments }\end{array} & \text { Assign- } \\
\end{array}$ & 5 & 7 & 0 & 0 & 1 & 0 & 1 & 1 & 4 \\
\hline $\begin{array}{l}\text { Submitting } \\
\text { assignments }\end{array}$ & 0 & 1 & 0 & 2 & 0 & 4 & 0 & 0 & 0 \\
\hline
\end{tabular}

TABLE VII

DATA ON NOT USED TOOLS (\%)

\begin{tabular}{|l|l|l|l|}
\hline & \multicolumn{3}{|c|}{ Not Used } \\
& \multicolumn{3}{|c|}{$2003 / 06 / 09$} \\
\hline Study Materials & 0 & 10 & 3 \\
\hline Dictionary & 31 & 13 & 44 \\
\hline Search & 86 & 57 & 78 \\
\hline Tests & 16 & 4 & 4 \\
\hline Sample Credit Test & 26 & 7 & 4 \\
\hline Syllabus & 9 & 7 & 11 \\
\hline Calendar & 5 & 6 & 8 \\
\hline E-mail & 18 & 14 & 11 \\
\hline Discussion & 19 & 6 & 8 \\
\hline Chat & 80 & 77 & 63 \\
\hline Setting Assignments & - & - & - \\
\hline Submitting assignments & - & - & - \\
\hline
\end{tabular}

The Not Used column situated in the centre of the scale displays numbers of those who did not use the tool. Information in tables are divided into three parts (IV, V, VI) because of required file formatting. Table 5 presents positive values $(\mathrm{Y}+++-\mathrm{Y}+)$, table $\mathrm{V}$ displays negative data (N- - N---) and in table VI Not Used tools are shown.

Figures in tables 6 and 7 clearly show students' satisfaction with most tools. Columns N---, N--, N- seldom provide other figures than zero per cent. The only situation 
is $\mathrm{N}$ - in Dictionary where $3-16 \%$ was slightly dissatisfied with this tool. On the other hand most students highly appreciated study materials, sample credit test, syllabus, calendar, e-mail and discussions. Although offered, students hardly use the search tool and chat. No data are provided in Setting assignments and submitting assignment because all students used them fort he described activities.

Tables 5-7 display the development and changes in using the Discussion tool during the monitored period. While in $2003 / 4$ totally $79 \%(49+18+12)$ evaluated it positive, $2 \%$ of students slightly negative (N--) and $19 \%$ did not use it at all, in $2006 / 7$ the positive evaluation reached $94 \%(61+21+12)$ and $6 \%$ did not use it, and in $2009 / 10$ totally $92 \%$ of students $(63+29)$ considered the discussion tool contributive, and $8 \%$ did not use it.

In Part Three of the questionnaire necessary financial requirements when studying in distance on-line courses. Table 8 provides data of two types. First, in the upper part the total sum of money is presented second, individual student's evaluation of the necessary amount is provided in the lower part of the table.

In spite of the fact the total amount of money required for studying in the distance on-line course is not low; the data in table 8 prove most students do not consider it high. From 81 to $92 \%$ of students spend max 500 CZK per month on expenses relating to on-line distance study which $7-17 \%$ of them consider high. These figures changed slightly during the monitored period.

To sum up the received results the descriptive statistics shows the three groups are similar in male/female members and possessing the computer at home. Most of them have their own notebook. They slightly differ in following criteria:

- the distance students commute to the educational institution: currently there are more "local" students,

- the year they graduated from the secondary school: current students are "younger", i.e. they graduated five and fewer years ago,

- the type of secondary school: currently more students from secondary technical schools enrol to the faculty,

- access to the Internet: these days all students have access to the Internet from home, which is one thirdincrease in comparison to 2003/4 academic year.

In the field of tool evaluation it is highly positive that most tools are appreciated $(\mathrm{A}+++$ to $\mathrm{A}+)$. The slightly negative opinions $(\mathrm{N}-)$ relate to the dictionary. There might have been two reasons why students were not satisfied with this tool. First, it was originally designed as glossary, i.e. the application was structured into two columns in one file. The traditional dictionary format would appreciate two files at least, one for each language (foreign language - mother tongue, and vice versa). In 2006 the LMS provider cancelled the original alphabet structuring which suited much more to the purpose of dictionary. The required format can be set but consequently it takes more time for data loading and students may consider it not user-friendly. Second, the survey ran within the IT English course, which may have reminded respondents their slightly negative experience just in this course and tool.

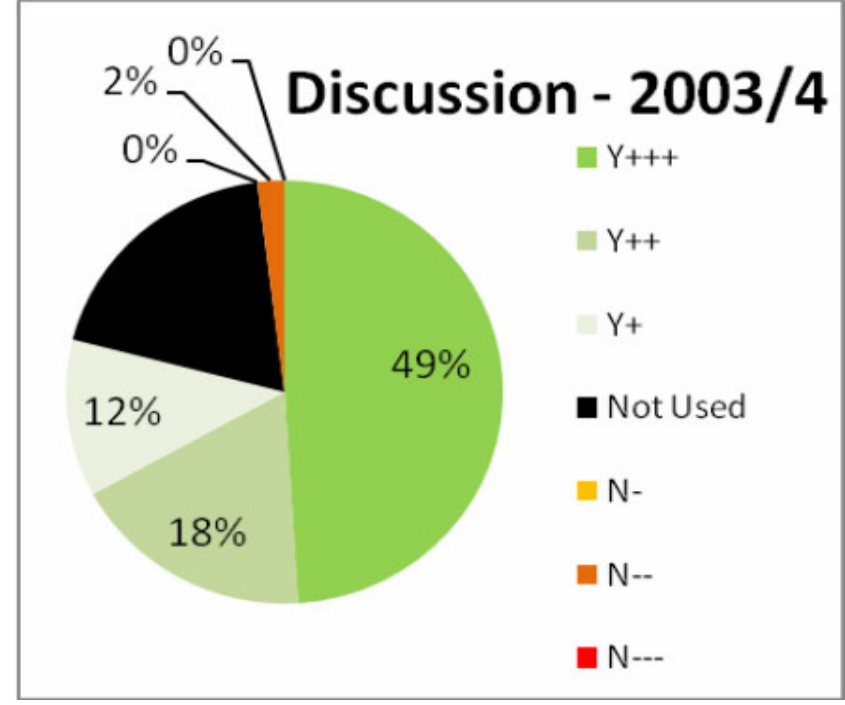

Figure 5. Discussions in 2003/4

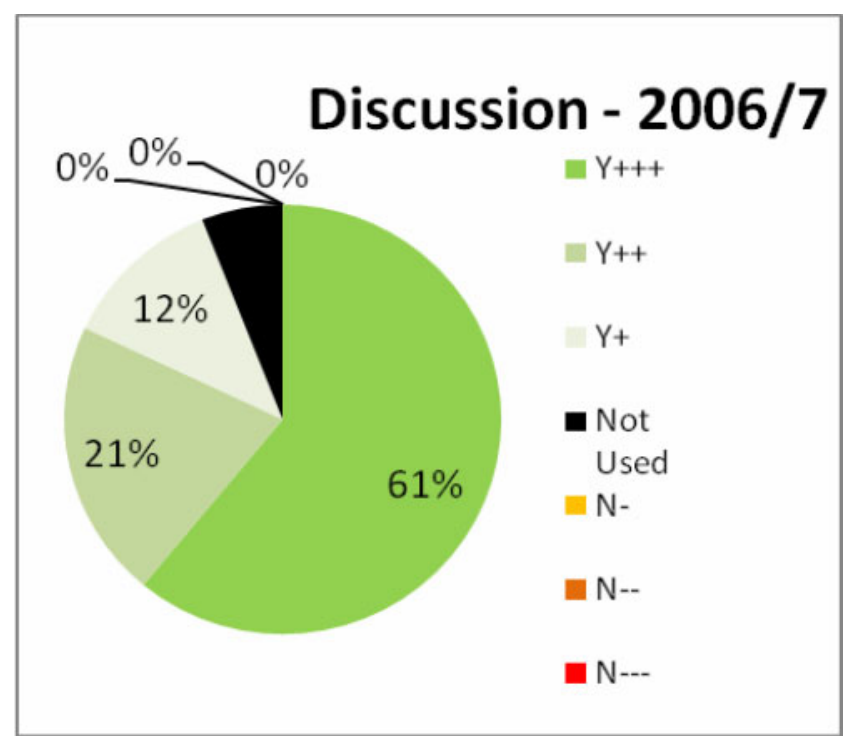

Figure 6. Discussions in 2006/7

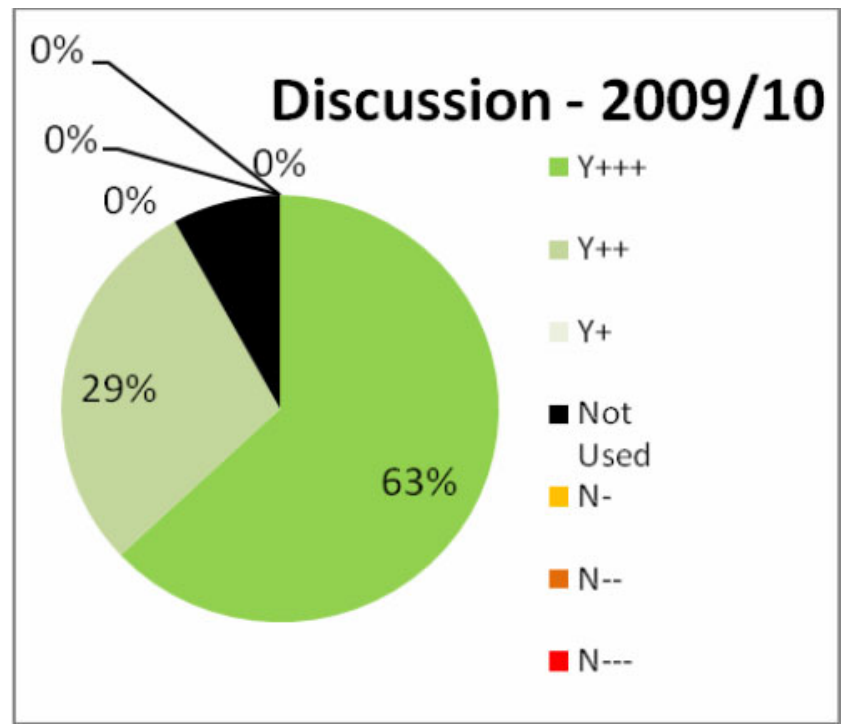

Figure 7. Discussions in 2009/10 
TABLE VIII. FINANCIAL REQUIREMENTS FOR STUDYING IN DISTANCE ON-LINE COURSES (\%)

\begin{tabular}{|l|c|c|c|}
\hline Amount (CZK) & $\mathbf{2 0 0 3 / 4}$ & $\mathbf{2 0 0 6 / 7}$ & $\mathbf{2 0 0 9 / 1 0}$ \\
\hline 0 & 33 & 41 & 22 \\
\hline $200-300$ & 38 & 26 & 41 \\
\hline $400-500$ & 14 & 14 & 29 \\
\hline $600-800$ & 5 & 7 & 0 \\
\hline $900-1,400$ & 10 & 12 & 4 \\
\hline More than 1,400 & 0 & 0 & 4 \\
\hline otal sum is high for me & $\mathbf{2 0 0 3 / 4}$ & $\mathbf{2 0 0 6 / 7}$ & $\mathbf{2 0 0 9 / 1 0}$ \\
\hline Strongly agree & 2 & 7 & 4 \\
\hline Agree & 5 & 10 & 11 \\
\hline Disagree & 25 & 29 & 26 \\
\hline Strongly disagree & 68 & 54 & 59 \\
\hline
\end{tabular}

Tests of ten types were also invited. Students considered them contributive, sometimes in lower degree. At the beginning of their work in LMS they had problems with being accurate enough when writing open-answer questions, which may discourage them a little, but it improved during a short-time period.

Communication tools were widely used because they belong to essential ones which enable to carry out the distance instruction. On one hand, e-mail and discussions were highly appreciated and hardly any student did not consider them contributive. On the other hand, chat was seldom used. The reason could be students found it redundant, they did not need any other way of communication, or they could use other tools out of LMS, e.g. ICQ. Syllabus and calendar were understood helpful as they support time management and thus help students meet all the requirements.

A large number of on-line distance courses which students had participated in before the survey started provided them with large experience in several subjects. Single courses were designed by different teams and run by tutors of different teaching styles. It is generally acknowledged that the instructor's (tutor's) teaching style should match the student's learning style. Felder says that mismatching can have consequences and cause a wide range of further educational problems. It favours certain students and discriminates others, especially if the mismatches are extreme [12]. On the other hand, if the same teaching style is used repeatedly, students become bored. Gregorc claims that only individuals with very strong preferences for one learning style do not study effectively, the others may be encouraged to develop new learning strategies [13]. Only limited number of studies has demonstrated that students learn more effectively if their learning style is accommodated [6]. Smith et al. found the same number (nine) of studies which showed that learning is more effective if there is a match, and the same number where there is a mismatch [in 14]. Mitchell et al. concludes that making the educational process too specific to a user may restrict the others [15].

The ICT-supported instruction is considered suitable and beneficial for learners of all styles. The reason is it offers a wide range of activities which can be aimed at any learning style and used by any teaching style instructor. The possibility of individualization of the educational processes from the both student's and teacher's point of view is its greatest advantage. Computer literacy is being understood to be essential by all students and most teachers. Didactics accepting the ICT implementation is the field is being developed.

It is obvious that results were influenced by the fact that respondents were related to the field of Information and communication technologies to some extent, both by interest and profession. The distance education is steadily spreading as it enables to accommodate requirements for study and work at the same time period. The current life style and social-economic demand for further education will support this way of education so it is highly desired teachers (tutors) had adequate competences and were able to design and run on-line distance courses in the efficient way.

\section{CONCLUSION}

The information and communication technologies have been implemented in the process of instruction and eLearning has become a standard in the large number of Czech educational institutions, so it is high time we paid attention to this field really systematically.

Within the ten-year history the seminars/conferences and competitions on eLearning have played the crucial role in this process, and have been included on levels of the Czech system of education. All the results mentioned above are undergoing more detailed analyses aiming at using the gained knowledge and experience in the further development of the process, thus contributing to optimizing the educational process.

Both the ICT and eLearning have become the natural part of the information society. Each developed state assures good education for its inhabitants to develop the key competences necessary for living in the current society. This objective is highly required in the field of engineering education, as the role of technology has been increasing in the society as well as demand for qualified engineers and technical subject teachers.

\section{ACKNOWLEDGMENT}

The paper is supported by the GACR Project N. $407 / 10 / 0632$ "A flexible model of the ICT supported educational process reflecting individual learning styles“.

\section{REFERENCES}

[1] M. McLuhan, " Understanding Media: The Extensions of Man," 1st Ed. McGraw Hill, NY, 1964.

[2] H. Zlamalova, "Analysis of university long-term plans in ICT," Proceedings Distance education and eLearning, Praha, 2006.

[3] K. Kveton, "The distance and online education," Praha, 2003.

[4] D. Nocar et al., "E-learning in the distance education," Olomouc, 2005.

[5] K. Kopecky, "Introduction to e-learning," Olomouc, 2005.

[6] HP. 2006. e-learning. Hewlett-Packard Development Company. [Online] [14 06 2011], http://www.hp.cz/e-learning/elearning.php.

[7] J. Wagner, "Nebojte se eLearningu," [Online] [11 03 2010], http://www.ceskaskola.cz/.

[8] European Commission, "The eLearning Action Plan: Designing tomorrow's education," Brussel : European Commision, 2001. 
[9] H. Zlamalova, "Introduction to the distance education," Olomouc, 2002.

[10] R. K. Logan, Definition of E-learning. [Online] [Cited 0609 2010]. http://www.managersforum.com/eLearning/.

[11] P. Poulová, M. Černá, M. and L. Svobodová, "University Network - Efficiency of Virtual Mobility." In Proceedings of the 5th WSEAS/IASME International Conference on EDUCATIONAL TECHNOLOFIES (EDUTE09). La Laguna: WSEAS Press, 2009, pp. $87-92$.

[12] R. M. Felder, L. K. Silverman, "Learning/Teaching styles in engineering education." Journal of engineering education, 78(8): 674-681, 1998.

[13] A. F. Gregorc, "Learning/teaching styles : potent forces behind them." Educational leadership, 36 : 234-238, 1979.

[14] F. Coffield et al. "Learning styles and pedagogy in post-16 learning. A systematic and critical review." Newcatle University report on learning styles. [online]. [cit. 2007-10-31]. http://www.Isda.org.uk/files/PDF/1543.pdf.

[15] D. P. Mitchell, "Learning style: a critical analysis of the concept and its assessment." London : Kogan Page, 1994

\section{AUTHORS}

I. Simonova is assistant professor at the Department of Applied Linguistics, Faculty of Informatics and Management, University of Hradec Kralove, Rokitanskeho 62, CZ-500 03 Hradec Kralove, Czech Republic (e-mail: ivana.simonova@uhk.cz).

M. Bilek is full-professor at the Department of Chemistry, Faculty of Science, University of Hradec Kralove, Rokitanskeho 62, CZ-500 03 Hradec Kralove, Czech Republic (e-mail: martin.bilek@uhk.cz) and full-professor at the Department of Chemistry, Faculty of Natural Sciences, Constantine the Philosopher University in Nitra, A. Hlinku 1, SK-949 74 Nitra, Slovakia (mbilek@ukf.cz).

Received 20 April 2012. Published as resubmitted by the authors 24 May 2012. 